\title{
Terrorism Pre-Detection Indicator in Malaysia
}

Borhanuddin Zakaria, Md Yazid Ahmad, Nik Abdul Rahim Nik Abdul Ghani, Muhammad Hafizi Rozali

To Link this Article: http://dx.doi.org/10.6007/IJARBSS/v11-i11/11550

DOI:10.6007/IJARBSS/v11-i11/11550

Received: 17 September 2021, Revised: 22 October 2021, Accepted: 29 October 2021

Published Online: 08 November 2021

In-Text Citation: (Zakaria et al., 2021)

To Cite this Article: Zakaria, B., Ahmad, M. Y., Ghani, N. A. R. N. A., \& Rozali, M. H. (2021). Terrorism PreDetection Indicator in Malaysia. International Journal of Academic Research in Business and Social Sciences, 11(11), $510-523$.

\section{Copyright: (c) 2021 The Author(s)}

Published by Human Resource Management Academic Research Society (www.hrmars.com)

This article is published under the Creative Commons Attribution (CC BY 4.0) license. Anyone may reproduce, distribute, translate and create derivative works of this article (for both commercial and non-commercial purposes), subject to full attribution to the original publication and authors. The full terms of this license may be seen at: http://creativecommons.org/licences/by/4.0/legalcode

\section{Vol. 11, No. 11, 2021, Pg. $510-523$}

Full Terms \& Conditions of access and use can be found at http://hrmars.com/index.php/pages/detail/publication-ethics 


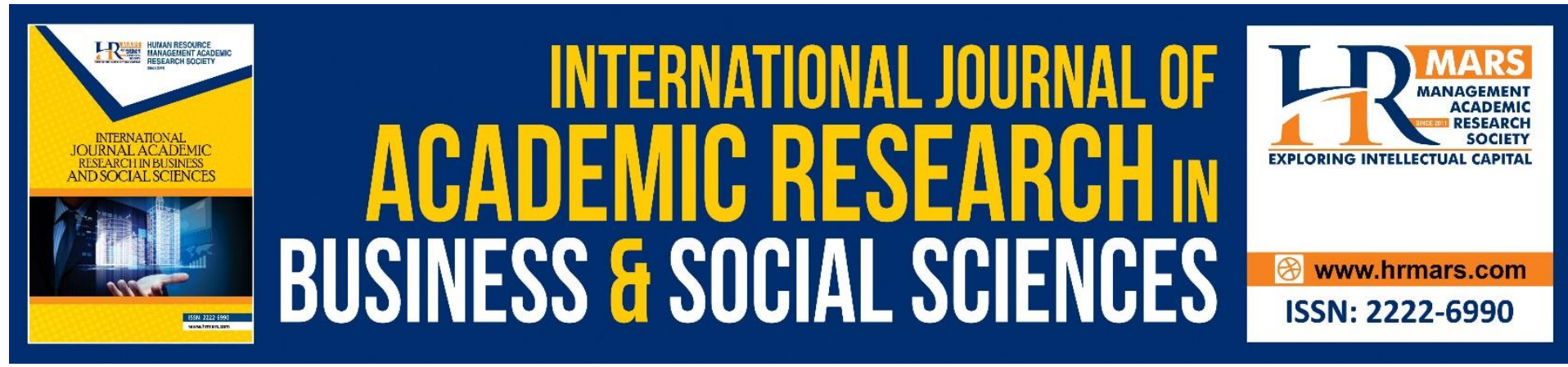

\title{
Terrorism Pre-Detection Indicator in Malaysia
}

\author{
Borhanuddin Zakaria'1, Md Yazid Ahmad², Nik Abdul Rahim Nik \\ Abdul Ghani ${ }^{2}$, Muhammad Hafizi Rozali ${ }^{1}$ \\ ${ }^{1}$ Fakulti Pengajian Kontemporari Islam, Universiti Sultan Zainal Abidin, 21300, Kuala Nerus, \\ Terengganu, Malaysia, ${ }^{2}$ Fakulti Pengajian Islam, Universiti Kebangsaan Malaysia, 43600 \\ UKM Bangi, Selangor, Malaysia.
}

Email: borhanuddin@unisza.edu.my

\begin{abstract}
This study discusses terrorist ideology, movement and activities detection in Malaysia. It is part of the efforts to create awareness among the Malaysian public about terrorism by providing insight or knowledge on terrorism, its issues and groups, and the legislation to prevent the movement in this country. Therefore, specifically, this writing aims to discuss terrorism in Malaysia. The main objectives are to examine terrorism concepts from the Islamic and Western perspectives, study terrorism-related issues in Malaysia, analyse the Malaysian legislation on terrorism, and investigate terrorism prevention measures according to the Malaysian Federal legislation. The author has referred to several authoritative sources from the Quran and the Sunnah, legislation provisions, and the opinions of figh scholars of various sects to explain terrorism reality. This qualitative study used content analysis in analysing the fiqh scholars' views and provisions in the existing written law in Malaysia. The study implies that it provides insight for the legislative body to introduce better legal provisions on terrorism; also, it prompts awareness among the public, especially on the understanding and knowledge on terrorism.
\end{abstract}

Keywords: Terrorism, Fiqh Scholars, Sects, Federal Legislation.

\section{Introduction}

Understandably, terrorism is not something new, and it is also never-ending. Terrorism is synonymous with terror, violence, extremism, and intimidation. It also involves killing regardless of age, race, and nation. In a devastating tragedy of the massive bombing on the World Trade Centre (WTC) on 11 September 2001 in New York, United States, which killed approximately 3000 people, the US government had accused al-Qaeda, an Islamic group, to be responsible for the bombing. It is regrettable when Islam is linked to terrorism. Ever since the WTC tragedy, a gruesome picture was painted on the image of Islam when the public worldwide has understood and convinced that Islam is a terrifying religion; a religion that preaches and uses terror or violence as the mean to achieve what it wishes. Therefore, the Muslims have become an easy target accused of committing such heinous crime in the US, leading to most Islamic groups labelled as terrorists. 
Hence, such serious sweeping generalisation and accusation to Islamic groups must be clarified by presenting the truth. The baseless accusation also equates jihad as Islamic teaching that encourages terrorism. The truth is that the concept of jihad and terrorism are entirely the opposite; jihad aims to strengthen Islam through the establishment of justice and the prevention of tyranny. On the contrary, terrorism permits or allows any violent action to intimidate to attain the desired goals or purposes.

Locally, terrorism is also a severe threat in Malaysia, with two infamous violent rebel incidents by the Al-Maunah and Tuhan Harun (The Aaron God) groups that shook the entire nation and were publicly discussed. The tragedies were high profile cases as they were among the first groups acquitted under section 121 of the penal code. Nevertheless, the incidents also demonstrated the Malaysian security force's credibility and capability to protect the country from enemy threats.

In general, the action and attack by rebels or terrorists are considered criminal action and case they can endanger national security and stability. This paper will reveal the existing legislation prescribed and implemented in Malaysia, the Islamic law and measures according to the Federal legislation in preventing and overcoming terrorism.

\section{Terrorism According to the Western Perspective}

Terrorist and terrorism have been a never-ending global discussion among nations. Generally, in this context, the word "terror" or "terrorism" has no fixed or universal definition. Based on the writer's examination, according to the Roman language, the root word for terror is "cimbricus terror", meaning "to scare". The meaning implies the intimidation and restlessness affecting soldiers during an intense war battle. Terminologically, during the French Revolution between 1789 to 1799, the meaning of the word was expanded and coined as "le terreur or terrer", referring to the use of extreme violence such as murder on individuals accused of treason. Tilly (2004) suggested that "terrorism" rooted in such extreme practice during the Revolution to pacify the state enemies. He stated that "terrorism was quite literally defined as government by intimidation as directed and carried out by the party in power in France during the Revolution of 1989-94 and policy intended to strike terror in those against whom it is adopted". While, Chailand and Blin (2007) stated that "definition of terror has persisted through global history and politics, with many scholars agreeing that the point of terrorism is to terrorise, with the act of doing so historically assumed by an organised force".

\section{Terrorism According to the Islamic Perspective}

In Arabic, terrorism is known as Al-Irhab, originating from the root word rahiba (ra-hi-ba), meaning threat. Terminologically, irhab can be understood as the emergence of intimidation due to terrorist or violent actions such as murder, riot, and bombing. According to Nizarudin (2017), Al-Irhab is defined as invoking intimidation; meanwhile, irhabi (terrorist) refers to a person who invokes intimidation in others or simply as someone who scares people.

Terrorism from the Islamic etymology can be divided into al-irhab (irhabiyyah) and al-hirabah. The writer believes that both terms have different contexts, yet, both remain under terrorism. 


\section{* Al-Irhab}

Terminologically, it means threat. Al-irhab aims to create intimidation and terror through the act of violence. Meanwhile, Al-irhabi means terrorist or the person who commits violence and terrorism. Meanwhile, al-hukm al-irhabi means a government style that governs the people the way it wishes by using violence to prevent any dispute and eliminate separation movements. Al-irhad can be equated to terrorism that is found in several verses of the Quran such as:

- Al-Araf, 7: 116

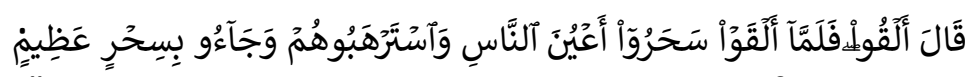

Meaning: Moses said, "You first!" So, when they did, they deceived the eyes of the people, stunned them, and made a great display of magic."

\section{* Al-Hirabah}

Al-Hirabah is a criminal act against a nation's security stability. Individuals involved in alhirabah use weapons intending to kill, cause damages and rob properties. Etymologically, alhirabah refers to a thief or a robber who commits a severe crime. They intentionally and openly seize public property. While terminologically, the Hanafiah suggests that al-hirabah refers to individuals or groups that use violence to steal people's property; they intimidate the public by using threats such as killing and confiscating their property.

Meanwhile, according to Shafi'iyyah, al-hirabah is "a person who goes out to seek and steal property or kill or intimidate people with violence and force in a secluded place. Imam Malik's view suggests that the meaning of al-hirabah is taking something using a deception, whether by force or not. Conclusively, al-hirabah is openly taking something or the property of other people by using violence.

\section{Terrorist Groups in Malaysia}

According to Bukit Aman Special Branch Counter-Terrorism Division (E8) principal assistant director Datuk Ayob Khan Mydin Pitchay, many terrorists have entered Malaysia and have been arrested by the Malaysian Royal Police since the end of the 1990s until today. Among the arrested groups are Jemaah Islamiah, Darul Islam, Harimau Pembebasan Tamil Eelam (LTTE), Abu Sayyaf, Al-Qaeda, Daesh and many more.

\section{Terrorism Issues in Malaysia}

The terrorists and extremist groups presence in Malaysia, to a certain extent, has negatively affected national security. The movement and the development of these groups are worrying as they could discretely commit any terrorist act at any given time. Generally, these groups are known for using the word jihad for a completely wrong reason, thus, intimidating the public to threaten the national law and order.

The inappropriate use of the jihad concept by these groups somehow has dramatically influenced a small number of Muslims in Malaysia. They manipulate the religion of Islam by using the jihad concept, suggesting that war is the only mean to establish an Islamic nation. Through such influence, various terrorist incidents have happened in this country, such as the Al-Maunah and Tuhan Harun incident. 


\section{* Al-Maunah Tragedy}

In the middle of 2000, Malaysia was shaken by the altercation between the national armed forces and individuals who called themselves the Al-Maunah group at Bukit Jenalik, Sauk Perak. The Al-Maunah staged the altercation to declare war against the Royal Highness of Yang di-Pertuan Agong and overthrow the ruling government at that time. The group assembled their base in Bukit Jenalik near the villages in the district of Sauk, Perak.

Harian Metro (2019) reported that the Al-Maunah group consisting of 27 individuals trespassed the Territorial Army Regiment camp in Gerik, Perak stealing weapons from the camp artillery store. Rozlin and Ismail (2020), in their article, stated that the founder of the Al-Maunah group, Mohamed Amin bin Mohamed Razali along with 29 of his followers, had carefully planned to access the Kuala Rhui army camp and Battalion 304 of the Territorial Army Regiment in the Temenggor Dam Perak by pretending to be senior army officers conducting a spot check. Using the disguise, they were able to steal 114 weapons and 18 thousand bullets.

Also, Al-Maunah extensively used the assembled base for various training to prepare them for the altercation. Among the training conducted was shooting practice. Due to the frequent practice, the locals of Bukit Jenalik could hear the reverberation of the shootings. They then reported the reverberation to the police, but the police yet to detect the actual location of the shootings.

Eventually, after a thorough investigation, the police located that the shootings' sound came from the Al-Maunah base. While the extremist group was preparing themselves to spark chaos and overthrow the government, the authority sent 300 armed forces to surround the area to prevent the group from leaving the area. SINAR (2020) reported that the Royal Malaysian Police Force (PDRM) had also taken over the operation by sending its armed forces to sneak into the Al-Maunah base. In the altercation, the Al-Maunah group had taken hostage four people. The hostages were two policemen Detective Corporal R Sanghadevan and Lieutenant General (Rtd) Datuk Seri Mohd Zaini Mohd Said, an army special force commando Trooper Mathew Medan, and a local man named Jaafar Puteh. They used terror and violence to demonstrate their resistance towards the government, and they also tortured and killed their hostages. Two of the hostages, Sanghadevan and Matthew Medan, were brutally murdered by the Al-Maunah founder.

The extremist group launched attacks from their base in Bukit Jenalik. On 5 July 2000, the shooting between the Al-Maunah and PDRM took place, one of the Al-Maunah member, Abu Bakar Ismail, was shot dead by the armed forces. Due to the incident, the Al-Maunah leader, Amin, returned fire in full force. Various approaches were used in the negotiation process between the armed forces and the extremist group, including psychological and spiritual. Chief Inspector Abd Razak Mohd Yusof headed the direct negotiation to persuade the alMaunah members to surrender themselves to PDRM voluntarily. Eventually, on 6 July 2000, the al-Maunah group was disintegrated as 11 of its members turned themselves into the authority.

During the negotiation, Lieutenant General (Rtd) Datuk Seri Mohd Zaini Mohd Said was held at gunpoint by the al-Maunah leader, Amin. A sudden tussled between the two men caused gunshot injury on one of the al-Maunah members when the Lieutenant General dodged a 
bullet fired from the weapon. After 60 seconds of struggle, Amin was defeated. The defeat directly ended the altercation and the four-day army and police operation in the area.

\section{* Tuhan Harun Tragedy}

On 10 November 2013, the assassination of Mohd Raffli Abdul Malik, the Chief of Religious Enforcement Division of the Pahang Department of Islamic Religion (JAIP), shook the entire nation. It is believed that he was murdered by cult members known as Tuhan Harun. The cult group was led by a man named Harun Mat Saad, aged 47 years. Seven individuals were accused of planning and executing the assassination of the officer. The individuals were Harun (47), his third wife Azida Mohd Zol (31), his driver Shaizal Eddie Nizam Shaari (38), and three followers, namely Jefferi Safar (37), Sumustapha Suradi (39) and Shamsinar Abdul Halim (37). Meanwhile, another one of the accused is still at loose.

The incident took place at 1.50 in the afternoon when a group of people wearing black robes and skull caps went to Mohd Raffli's house. While waiting for Mohd Raffli to open the door, the Tuhan Harun members fired three gunshots at the victim. Two of the bullets hit the victim's chest and one missed. Due to the shots, Mohd Raffli died on the spot.

Chief Police Officer Tan Sri Khalid Abu Bakar stated that the police believed that a cult linked to Mohd Rafli' duty as the enforcement chief carefully planned the assassination. At that time, among the duties or cases handled by Mohd Raffli were the spread of the Shia and Tuhan Harun teachings. Abdullah (2013) stated that the Pahang Department of Islamic Religion detained the Tuhan Harun group as they were involved in cult and scams.

In his article, Husin (2013) stated that in April 2013, the officer raided places in Bandar Indera Mahkota and Jalan Bukit Ubi, which they believed to be the cult teaching centres. Various documents, laptops, thumb drives, CDs, and iPads containing computer software and teaching methods belonging to the cult were confiscated as evidence to facilitate the investigation.

Harun was also charged and wanted by the National Bank for fraud cases involving RM200 million in cash since 2011. Therefore, PDRM believed that the assassination was Tuhan Harun revenge against Mohd Raffli as his enforcement operations obstructed his teachings. The Pahang Police and JAIP detained Tuhan Harun followers to facilitate the investigation of the case. Meanwhile, on 20 November 2013 at 3.30 PM, the Johore Police Chief Datuk Mohd Mokhtar Mohd Shariff detained the Tuhan Harun's leader and his third wife in a raid in Bandar Baru in the district of Tangkak Johore. The suspects were handed to the Pahang police for further investigation.

Bernama (2014) reported that the Deputy Public Prosecutor Khamizah Salleh applied to the High Court to conduct parallel trials of Mohd Raffli murder case, and Judge Datuk Ab granted the application. Karim Ab. Rahman. Judge Ab Karim decided that the trials would take place from 27 October 2014 until 31 October 2014. Those involved in the trials were Harun Mat Saad, Azida Mohd Zol, Shaizral Eddie Nizam Shaari, Jefferi Safar, Sumustapha Suradi, and Shamsinar Abdul Halim. They were accused of criminal conspiracy intending to kill Mohd Raffli on 10 November 2013. They were also charged with murdering at the victim's house in Bandar Indera Mahkota 2 at 1.50 PM. 
As the result of the trials, the Kuantan High Court sentenced to death two of the cult followers, Sumustapha Sumadi and Shamsinar Abdul Halim, as they were found guilty of killing Mohd Raffli at his house; meanwhile, other four of the accused were released as the prosecutor failed to prove their involvement in the case.

\section{The arrest of DAESH (IS) Members}

On 21 March 2017, the Malaysian Royal Police Force suspected that 234 Malaysians were involved in the militant terrorist group known as Daesh (IS). PDRM also identified that 95 Malaysians had joined the terrorist group in Syria; 30 were dead or killed; meanwhile, eight of them returned to Malaysia and detained upon arrival.

On 21 July 2018, a female suspect was detained and prosecuted for planning a terrorist act in Kuala Lumpur to be carried out during the General Election. For the first time, this case revealed the involvement of Daesh female members in executing a terrorist act individually. It has become the latest trend of the IS group to use its female members to commit violent activities in this country. Usually, the use of women in the IS group is to carry out petty duties such as a mediator to transport fund to the IS members in other countries and as a secondary player, i.e., as their husband's supporter in spreading the salafi's ideologies and others.

The woman was detained on 9 May 2018 as she was charged with the attempt to blow up a voting centre in Puchong using a vehicle fixed with a bomb inside it. Besides that, the suspect was also planning vehicle bomb attacks on worship venues of other religions in Malaysia. The suspect is a female aged 51 years old, a mother of two children. She was also among the pioneering female leaders of a militant group pro to IS. On top of that, PDRM confirmed that the suspect's husband did not know that the suspect was an active terrorist group member who planned acts of terrorism. Apart from that, PDRM also assumed that she had been making long-distance communication with 600 people via Facebook and WhatsApp. Hence, the suspect had communicated with the IS members in Europe. The suspect, via long-distance communication, gathered information to launch a violent attack without being detected by the country's authorities.

Thus, the authorities must always be alert, cautious, and careful in monitoring and detecting these groups of people as they use different approaches to launch their attacks and have become more radical using outside of the box strategies. Their strategy of using and sending female militant members causes the terrorist groups' movement to become harder to detect by the plain eyes.

\section{Legislation Related to Terrorism in Malaysia}

The spread of terrorism activities is becoming more intense and threatening to national security. Hence, the Malaysian government introduced The Security Offences (Special Measures) Act 2012 (SOSMA). However, the Act was later repealed, and the government introduced The Prevention of Terrorism Act 2015, known as POTA 2015, to handle militant activists in Malaysia.

\section{i. $\quad$ The Security Offences (Special Measures) Act 2012 (SOSMA)}

The government introduced The Security Offences (Special Measures) Act 2012 (SOSMA) to deter and constraint terrorist activities that can threaten and disrupt the nation and the 
public's law and order. The Act outlines terrorism as violence planned towards individuals and properties or intimidating several civilians in a particular country.

\section{ii. The Prevention of Terrorism Act 2015 (POTA)}

Meanwhile, POTA 2015 is established to deter and suppress the actions and supports towards violence involving terrorist organisations from several foreign countries. POTA 2015 is also established to ensure that each terrorist cannot escape all forms of legal actions that a country has determined. It also aims to ensure the civilians and the country's safety and security to protect them from being disturbed by the enemies and the parties involved in terrorism. The legislation is the controlling measure for anyone suspected of being actively involved in a terrorist organisation or terrorist activities. Most critical terms in POTA are related to terrorism.

The Act provides a better explanation about the offences within the actual meaning of terrorist actions; it is also legislation in the form of a preventive measure against the actions and supports towards terrorist activities involving individuals and terrorist organisations in the country.

The Act is also known as Act 769, containing five sections, i.e., the Preliminary, Power of Arrest and Remand, Inquiries, Detention and Restriction Orders and General. The reading of this Act 769 must be done with other Acts such as Act 574 Criminal Procedure Code, Terrorism Financing Prevention Act, Registration of Criminals and Undesirable Persons Act (Act 1969) and Money Laundering Prevention Act. There are various offences and punishments under terrorist activities, which can be found in Section 130B (1) that provides a more detailed meaning of terrorism. The Section defines "terrorist" as any person who commits, or attempts to commit, any terrorist act; or (b) participates in or facilitates the commission of any terrorist act. Meanwhile, Section 130B (2) explains the action that can be considered as terrorist acts, which are:

a) an act or threat that belongs to actions categorised under Section (3), not the ones under Sub Section (4).

b) The act is carried out to pursue something political, religious, and ideological in nature.

c) The act also covers intimidating the public and influencing or forcing the ruler or the government.

The subsequent Section of 130 B (3) of the Penal Code explains the actions categorised as a terrorist act if the followings are done:

a) inflicts serious bodily injury to a civilian person,

b) endangers a person's life,

c) creates a severe risk to the health or the safety of the public or a section of the public,

d) damages public property,

e) causes the death of a civilian person,

f) uses firearms, explosives or other lethal devices,

g) releases hazardous elements such as toxic chemicals or microbial or other biological agents or toxins to civilians and the environment, and 
h) intends to disrupt the computer system or provision for the communication infrastructure, financial or banking service and many more.

Hence, it can be concluded that Act 769 is the prevention means for any terrorist act stated in the Penal Code that can cause a person to be a suspect despite the terrorist act has not been performed yet.

\section{Fighting Against Terrorism According to the Federal Constitution}

Every nation and government views terrorism as a serious matter. Malaysia is also a part of the discussion about terrorism. Malaysia has implemented various legislation and conducted parliamentary discussions to ensure the best measure to suppress terrorist activities that attempt to sneak into the country and commit terrorism or bring ideologies that are considered a threat to the nation's and civilian's peace and harmony. Therefore, the board members have determined several matters related to terrorism, among others, which are:

\section{i. Article 149}

Article 149 is legislation to fight against the actions that are detrimental to public peace and harmony. The Law provision to prevent and suppress any terrorist action can be legally executed when any action within or outside the Federation has been deemed a threat. These actions can be intimidating the public via action planned, rebelling against the Royal Highness Yang di-Pertuan Agong or any Government in the Federation, obstructing supplies or services to the public or inflicting harm to law and order of the Federation.

\section{ii. Article 150 - Proclamation of Emergency}

Proclamation of Emergency is a law made under Clause 1 of the Article that allows the issuance of emergency in the event of an incident that threatens the security, safety, and peace of the civilians and economy in the Federation. Thus, Yang di-Pertuan Agong can issue a statement or the proclamation of emergency.

\section{Islamic Legislation (The Law of Bughah)}

Etymologically, the word bugha was taken from Arabic, بنى (bagha) meaning "demanding for something", the synonym of bagha is ظلم (zalama), meaning unjust or oppressing. Bugha is then defined as asking for something that breaches a person's right and unlawful for the person who asks for it. According to Syarifuddin (2010), linguistically, bugha means demanding something. This word is often used in the Qur' an and frequently means to demand something.

Besides that, Putra (2011) stated that bugha also often refers to rebel. Rebel refer to someone who has gone beyond the limit that he is supposed to follow or abide. According to the shariah terminology, rebels refers to a group of Muslims revolting against or opposing an Islamic government, breaching and disobeying orders or obstructing the rights of Allah and fellow human beings. Initially, the term refers to going against or having no intention to obey or follow orders and at the same time revolting against the government. Besides that, bugha also means everything that is being demanded and rebelled. In short, bugha means rebelling against the ruler and the legitimate government power.

This definition has been formulated and presented by the imams of the four Islamic schools worldwide. According to the Hanafi School, the meaning of bugha is derived from the 
perspective of obedience to a leader or an imam that is the head of a state through legal manners and truthful reasons. The Maliki and Shafie School suggested a more detailed meaning of bugha: a group of Muslims who rebels against the ruling party or the government to overthrow a legitimate leader. In comparison, the Hanbali school emphasises disobedience towards leaders regardless of just or unjust leaders.

Audah (2018) stated that bughah is an action to oppose the law by rebelling against the existing, legitimate ruler aiming to overthrow and replace the ruler with a new one based on specific reasons. According to Zuhaili (2011), bugha is defined as an action by certain groups among the Muslims that attempt to commit rebellion and treason towards those vested with authority. Therefore, Al-Juzairi (2014) suggests that bughah or al-baghyi is a group of individuals who has the strength to revolt against a leader or ruler using logical and reasonable justifications. Using such justification, they opt to become more radical and reject to follow and obey the existing ruler.

Based on the definitions presented above, the writer concludes that bughah is a group rebelling against a ruler to overthrow the government.

\section{* Law on Bughah}

The Quran is explicit on the prohibition of bughah as it is a form of objection that can cause an uproar among people. Hence, the scholars have referred to some evidence from the Quran on the prohibition of bughah in Islam.

- Al-Hujarat: 9

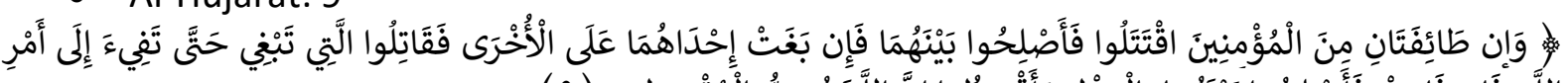

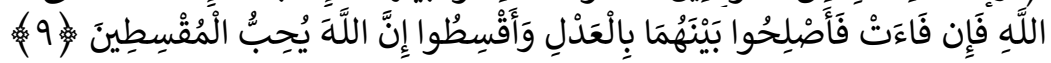
Meaning: "And if two factions among the believers should fight, then make settlement between the two. But if one of them oppresses the other, then fight against the one that oppresses until it returns to the ordinance of Allah. And if it returns, then make a settlement between them in justice and act justly. Indeed, Allah loves those who act justly."

- Al-Hujarat, 49: 10

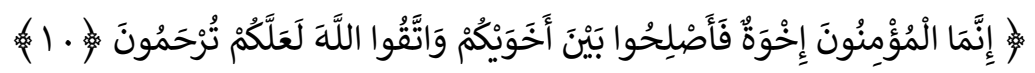

Meaning: "The believers are but brothers, so make settlement between your brothers (who were rivalling) and fear Allah that you may receive mercy".

The verses imply that there should be a proper and fair intervention to resolve the conflict in a dispute between individuals or groups. In addition, the verses also mean that conciliation is the best approach to resolve dispute and rebellion towards the head of state.

Ibn-Taimiyah, in the book of al-Siyasah al-Syar'iyyah, stated that the $10^{\text {th }}$ verse of chapter alHujurat is the answer to the $9^{\text {th }}$ verse of the chapter. The $10^{\text {th }}$ verse of the chapter is the supporting statement explaining that the resolution to human beings' disputes is via the conciliation approach. On top of that, the verses also stress the importance of a mediator's role in a dispute resolution process: the person must be just, fair and uninvolved in problems related to the disagreement. 
In addition, the head of state or ruler is also responsible for trying to resolve the disputes, such as offering advice and alike to the rebellious groups that intend to topple the existing government. According to Zuhaili's opinion, the verses from the al-Hujurat chapter also imply that a head of state must undertake a conciliation effort with the bughah group.

- Al-Nisa, 4: 59

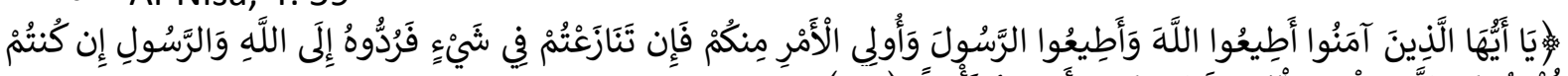

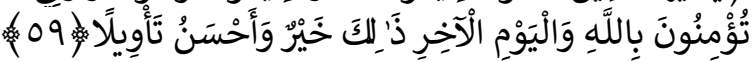

Meaning: "O you who have believed, obey Allah and obey the Messenger and those in authority among you. And if you disagree over anything, refer it to Allah and the Messenger, if you should believe in Allah and the Last Day. That is the best [way] and best in the result.

The $59^{\text {th }}$ verse of the chapter an-Nissa' reveals Allah's instruction to human beings to obey Him and His messenger by fulfilling the obligatory and the sunnah as well as staying away from what He has prohibited. In addition, the scholar also stated that Allah orders human beings to obey those in authority because they are entrusted with power upon people. Among the individuals with such power is the head of state, i.e., rulers, judges and the fatwa members.

\section{* Conditions for Bughah Punishment}

According to al-Mawardi, the bughah punishment can be carried out based on the impact of the terrorist actions. He mentioned that terrorist actions could be viewed in two motives: an action directed towards war or an action limited to a threat. Therefore, the motives of the action must be differentiated to ensure the bughah punishment is used accordingly and appropriately. If the terrorist action is only a threat, not directing to war, a warning should be sufficient.

Moreover, Ahmad Fathi Bahansi suggested that four groups belong to the bughah category. The groups are people who denounce their imam without excuses, people who denounce their imam without solid reasons and reject as well as refuse to obey the obligations, the khawarij group accusing Saydina Ali r.ha and Saydina Usman r.ha as a kafir and people who disobey orders and instructions of the imam with solid reasons and strive towards the preparation to revolt. Four conditions must be met to undertake the bughah punishment, which are:

i. The group has strength that can threaten the ruling stability.

ii. The group's conspiracy of going against the ruling power must be proven.

iii. The rebel group have solid evidence and reasons.

iv. The ruler must undertake a conciliation effort before actions to fight against the group.

After all the conditions are met, the bughah punishment can be carried upon the rebels; the ruler or head of the state must fight against such groups. The objective of the bughah punishment is to eliminate the intention and the urge to conspire against the rulers and as a lesson and reflection for the Muslim society. The war over the rebel groups by the government must depend on the circumstances of the war; if the conflict is resolved and a truce is achieved, then the war is considered over, and all fights shall cease immediately. 


\section{Conclusion}

In conclusion, in Malaysia, legislation to counter terrorist activities and movement has successfully helped the government detect and deal with the threats. Besides that, Islamic law also allocates appropriate legislation to handle problems related to terrorism. Hence, the legislation on terrorism or rebellion is a critical factor in the government administration to ensure the nation's economy, political and social peace and well-being.

\section{References}

Majid, A. (2014). Terorisme di Lingkungan Kelompok Muslim, Jurnal Substantia, 16 (1).

Armandhanu, D. (2016). Katibah nusantara, sayap melayu ISIS dan ancaman bagi Asia. http://www.cnnindonesia.com/internasional/20160125131234-106-

106475/katibahnusantara-sayap-melayu-isis-dan-ancaman-bagi-asia/ [19 August 2016].

Hassan, A. S. A. (2016). Daesh: Kebangkitan dan Pengaruh Media Sosial, Jurnal Komunikasi Malaysian Journal of Communication, 32 (2), 386-387, file://C:/Users/User/Downloads/16487-72014-1-PB\%20(1).pdf.

Alazeg, A. A. (2016). Management of Savagery. 44. Pittsburgh: Dorrance Publishing Co.

Astro Awani. (2016). Dua pengikut 'Tuhan Harun' dijatuhi hukuman mati, 27 December 2016, link https://www.astroawani.com/berita-malaysia/dua-pengikut-tuhan-harun-dijatuhihukuman-mati-127092.

https://www.academia.edu/35166595/GERAKAN_EKTREMIS_DI_MALAYSIA.

Dahlan, A. A. (2002). Ensiklopedi Hukum Islam, cet. 2. Jakarta: Ichtiar Baru van Hoeve. 1091.

Al-Jazairi, A. B. J. (2014). Minhaj al-Muslim, ed. In, Minhajul Muslim: Pedoman Hidup Seorang Muslim, (trans: Ikhwanuddin Abdullah dan Taufiq Aulia Rahman). Jakarta: Ummul Qura. 989.

Ar-Razi, A. H. A. F. Z. G. (1979). Mu'jam Maqayis al-Lughah. Beirut: Darul Fikr. 271.

Syarifuddin, A. (2010). Garis-Garis Besar Fiqih. Jakarta: Kencana Prenada Media Group. 310.

Bernama. (2014). Kes tuhan Harun dan pengikut bunuh pegawai JAIP dibicara serentak, 23 June 2014, link https://www.astroawani.com/berita-malaysia/kes-tuhan-harun-danpengikut-bunuh-pegawai-jaip-dibicara-serentak-38249.

Mahmud, F. (2017). Gerakan Keganasan dalam Masyarakat Islam (Analisis Gerakan Al-Qaeda), 9 Nov 2017

https://www.researchgate.net/publication/321024766_GERAKAN_KEGANASAN_DALA M_MASYARKAT_ISLAM_AL-QAEDAH.

Putra, D. D. O. (2011). "Hukuman bagi Pelaku Tindak Pidana Bughat". Jurnal Media Islam dan Hukum. 1 (2).

Harian Metro. (2019). Tak dapat lupa tragedy Al-Maunah, 19 September 2019, link https://www.hmetro.com.my/mutakhir/2019/09/498259/tak-dapat-lupa-tragedi-almaunah.

Black, H. C. (1990). Black's Law Dictionary 6th Edition, St. Paul-Minn: West Publishing.

Al-Jauziyyah, I. Q. (2008). Zad al-Ma'ad fi Hadyi Khair al-'Ibad, ed. In, Zadul Ma'ad; Panduan Lengkap Meraih Kebahagiaan Dunia Akhirat, (trans: Masturi Ilham, dkk), 7. Jakarta: Pustaka al-Kautsar. 25.

Rozlin, I., \& Ismail, A. I. (2020). Sinar Harian, retrieved from https://www.sinarharian.com.my/article/73757/BERITA/Jenayah/AI-Maunah-tewasdi-Bukit-Jenalik , 14 Mac 2020. 
Salleh, K., \& Ariffin, S. Z. (2017). Ajaran Sesat Harun Bin Mat Saat: Analisis Ajaran, Perkembangan dan Pengaruhnya di Kuantan, Pahang, Proceedings Of The International Conference On Islam, Development And Social Harmony In Southeast Asia. 434-435, http://aias.pnu.ac.th/ckfinder/userfiles/files/43\%20Kamarudin\%20432-441.pdf.

Salenda, K. (2009). Terorisme dalam Perspektif Hukum Islam, Ulumuna Jurnal Studi Keislaman, 13(1), direct link

https://www.researchgate.net/publication/294720809_TERORISME_DALAM_PERSPEK TIF_HUKUM_ISLAM.

Jamal, K., \& Kadarusman. (2014). Terminologi Pemimpin dalam Al-Quran: Studi Analisis Makna Ulil Amri dalam Kajian Tafsir Tematik, An-Nida: Jurnal Pemikiran Islam, 39(1), 121. file://C:/Users/homeuser/Downloads/869-1980-1-SM.pdf.

Maisara. (2020). 'Yang Di Pertuan Agong Ampunkan Ahli Al-Maunah, Ini Cerita Tentang Mereka', 23 August 2020, pautan https://orangkata.my/sejarah/yang-di-pertuanagong-ampunkan-ahli-al-maunah-ini-cerita-tentang-mereka/.

MalaysiaKini. (2013). Tuhan Harun ditahan di Tangkak, Bernama, 20 November 2013, link https://www.malaysiakini.com/news/247164.

Wajdi, M. B. N. (2017). Islam dan Radikalisme (Mengurai Makna Terorisme), direct link file:///C:/Users/User/Downloads/islam\%20dan\%20terorisme\%20(1).pdf.

Ismail, M. H. (2019). Artikel Sinar Harian: 809 Anggota Kumpulan Pengganas Ditahan Sejak 1990. Pautan, https://www.sinarharian.com.my/article/58443/BERITA/Nasional/809anggota-kumpulan-pengganas-ditahan-sejak-1990.

Nordin, M. K. N. C., \& Nazer, M. S. M. (2020). Faktor Penglibatan Belia Muslim Malaysia dengan Terorisme: Analisis Perspektif PDRM dan Panel Pemulihan Deradikalisasi, Jurnal Usuluddin (1).

Salleh, M. S. (2018). Sanksi Bughah: Studi Komparatif antara Fikih Syafi'iyyah dan Akta 574 Tahun 2002 Tentang Kanun Keseksaan, Fakulti Syariah dan Hukum Universiti Islam Negeri Ar-Raniry Darussalam-Banda Aceh.

Aqma, N. (2017). Ajaran Sesat di Malaysia, Politeknik Malaysia Mukah, 12, link https://fliphtml5.com/riph/wmyc/basic.

Musa, N. (2017). Ulasan Perundangan Akta Pencegahan Keganasan 2015, Fakulti Undangundang, Universiti Kebangsaan Malaysia, 211-214.

Abdullah, N. (2013). Pengikut Kumpulan Tuhan Harun Dipercayai Terlibat dalam Kes Pembunuhan Ahmad Raffli, MStar, link, https://www.mstar.com.my/lokal/semasa/2013/11/12/pengikut-kumpulan-tuhanharun-dipercayai-terlibat-dalam-kes-pembunuhan-ahmad-rafli, 12 November 2013.

Husin, N. N. (2013). Dua Premis Perniagaan Pengikut Tuhan Harun Ditutup, Mstar, 13 November 2013, link, https://www.mstar.com.my/lokal/semasa/2013/11/13/duapremis-perniagaan-pengikut-tuhan-harun-ditutup.

Hassan, S. A., \& Khairuldin, W. M. K. F. W. (2020). Research Design Based on Fatwa Making Process: An Exploratory Study. International Journal of Higher Education, 9(6), 241-246.

Said, N. A., \& Khairuldin. (2017). Freedom of Speech in Islam and its Connection with Street Demonstrations. International Journal of Academic Research in Business and Social Sciences, 7(4), 122-129.

Khairuldin, Embong, A. H., Anas, W. N. I. W. N., Ismail, D., Ibrahim, I., \& Fauzi, N. (2017). Freedom of Speech: A Comparative Study between Islam and Malaysian Laws. International Journal of Academic Research in Business and Social Sciences, 7(2), 22226990. 
Ibrahim, I., \& Khairuldin. (2017). Fatwa as a Medium Da'wah: Studies on the Role of Mufti as a Preacher. International Journal of Academic Research in Business and Social Sciences, 7(4), 10-18.

Riswadi. (2010). "Perbuatan Pidana Bughah dalam Hukum Pidana Islam”. Jurnal al-Syari'ah. $3(3)$.

Hawwa, S. (2004). Al-Islam, ed. In, al-Islam, (trans: Abdul Hayyie al-Kattani, dkk). Jakarta: Gema Insani. 366.

Sandler, T. (2014). The Analytical Study of Terrorism: Taking Shock, Journal of Peace Research, $51(2)$.

Zuhaili, W. (2011). Al-Fiqh al-Islami wa Adillatuhu, ed. In, Fikih Islam: Jihad, Pengadilan dan Mekanisme Mengambil Keputusan, dan Pemerintahan dalam Islam (trans: Abdul Hayyie al-Kattani, dkk), 8. Jakarta: Gema Insani. 208.

Zuhaili, W. (2012). Al-Fiqhu asy-Syafi'i al-Muyassar, ed. In, Fiqih Imam Syafi'i: Mengupas Masalah Fiqhiyyah Berdasarkan al-Quran dan al-Hadis, (trans: Muhammad Afifi \& Abdul Hafiz), 2(3). Jakarta: Al-Mahira. 398.

York, R. (2015). Know thy enemy: Islamic State of Iraq and the Levant. North Carolina: Lulu Press Inc.

Stuurman, Z. (2019). Terrorism as Controversy: The Shifting Definition of Terrorism in State Politics.

Yaakobb, Z. A., \& Long, A. S. (2015). Terorisme Sebagai Cabarang Ideologi Muslim: Masa Kini: Satu Analisis dari Perspektif Falsafah, International Journal of Islamic Thought, 7. 